\title{
POSITIONAL EMPHASIS IN THE MODERN LITERARY TEXT
}

\section{${ }^{\mathrm{a}}$ SVITLANA HALAUR, ${ }^{\mathrm{b}}$ RUSLANA SHRAMKO, 'SVITLANA PEDCHENKO}

${ }^{a}$ National University "Yuri Kondratyuk Poltava Polytechnic", 24 Pershotravnevyi Ave., Poltava, Ukraine, 36011

${ }^{b}$ Poltava V. G. Korolenko National Pedagogical University, 2 Ostrohradskyi St., Poltava, Ukraine, 36000

${ }^{c}$ Poltava V. G. Korolenko National Pedagogical University, 2 Ostrohradskyi St., Poltava, Ukraine, 36000

email: ${ }^{a}$ svitlana.galaur@gmail.com,

bshramen1atk02006@gmail.com, ${ }^{\text {c}}$ svpedchenko@gmail.com

Abstract: The given article touches upon one of the most relevant in modern psycholinguistics problems of literary cognition of reality by the addresser and perception of his knowledge by the addressee. A positional emphasis has therefore been analysed as a productive way of regulating the reader's perception of the text information. The research focuses on the relevant exposure of all the traits of lingual units' actualization and on the further sustainable in-depth description of its linguistic techniques. The investigation grounds on up-to-date methods of literary texts' analysis, particularly on lingual-poetic interpretation, regulatory structuring as well as on information-content one. The psycholinguistic experiment and the survey likewise the method of gradual scaling as its constituents revealed their productivity.

Keywords: positional emphasis, regulatory technique, stylistic technique, text regulating.

\section{Introduction}

The topicality of the research. Up-to-date psycholinguistics comprehends a large array of issues of the text perception, in terms of which the proper linguistic approach of the solution disclosed its inefficiency. Having been provided by the facts of interaction of mental and lingual mechanisms generating / decoding information, this scientific branch appeals to lingual consciousness within the text scilicet the inner process of programming and regulating the outer activity via lingual tools. In these terms, the high priority of the regulation theory of the literary text for diverse psycholinguistic research is irrefutable. Primarily, it targets to capture lingual stimuli of the cognitive activity of an addressee, who projects the directly expressed content onto the deep layers of the literary work, going from the perception of the text to its understanding. Likewise, the regulation theory approach makes a framework to all-embracing analysis of the regulatory means' ways of organization in the text and the design of regulatory microstructures, thus, to decipherment of the unfolding of the text aesthetic content.

Problem stating and analysis of previous studies. Actualisation represents the universal way of drawing reader's attention to the textual units, significant from communicative point of view. The mentioned above lingual phenomenon is traditionally found in the focus of philologists' studies, being interpreted on the base of various theories, they are, particularly, the theory of tension (V. Shklovskyi), advancement (representatives of Prague Linguistic Circle, and I. Arnol'd), dominants (V. Kukharenko), profiling (R. Langacker), deviation from the norm (I. Arnol'd). Quite a while the actualisation appeared to be identical to the expressiveness of language, the latter led to symbiosis of some linguistic concepts, videlicet expressive actualisation, expressive means of image-emotional actualisation, etc. It is worth mentioning that the actualisation and the expressiveness of textual units tend to be interrelated, though not interchangeable terms. Their effective usage secures the successive performance of the characteristics of miscellaneous categorical groups, namely regulation and expressiveness, in the text. As an aesthetic category, expressiveness incorporates evaluation and emotionality. Generated by different tropes and figures, the expressiveness emerges in those places of the text, where one can see a stylistic request for it and actualise the necessary content by means of regulation, according to author's intention. The expressiveness underlies the regulation, which utilizes aesthetic categories to highlight crucial content constituents of the multiplex information system of literary text.
The purpose of the research appears to elicit peculiarities of lingual units' actualisation via regulation means of positional emphasis and to provide the further in-depth analysis of its linguistic techniques. In order to fulfil the above-mentioned goals, it is essential to expose all conceivable macro-/ microcontext varieties of positional emphasis in literary texts of the present-day Ukrainian prose, likewise to differentiate regulatory and stylistic devices.

\section{Materials and Methods}

The given article has its base on the contemporary methods of the literary texts' analysis scilicet lingual-poetic interpretation, providing exposition of the content on the background of system-semantic relations of multileveled language units, regulatory structuring, aiming the observation on regulators as stimulants of various communicative effects, and informationcontent, focusing on the analysis of semantic development of the text. In addition, the psycholinguistic experiment, particularly the survey and the method of gradual scaling, opened to be productive. The respondents were students-philologists (100 persons in total).

\section{Results and Discussions}

The law of Hermann Ebbinghaus, German psychologist who pioneered the investigation of the rule of "borderline" (Ebbinghaus, 2011), successfully proved in numerous experimental studies, declares, "the beginning and the end of any information series are stored in human memory better than its middle part” (Roeskelein, 2006, 548). This statement particularly retains the function of the ground to the positional emphasis regulatory way as the promotion of text elements in "strong positions" (Arnol'd, 1978, 24). In consequence, given technique makes strong hierarchy of the content constituents, establishing the further links between adjacent/distant singlelevelled / multileveled text elements and simultaneously empowering the aesthetic perception of the artistic message.

In fact, the positional emphasis techniques have routinely been opted at both macro- and microcontext levels. The macrocontext techniques of the positional emphasis are relevant for obligatory (around-text and text) as well as optional (around-text) elements.

Usually the title complex obtains the strong text position, unveiling the traits of a medium in the addresser-addressee code; also it determines "the horizon" of readers' expectations. Perception and understanding of any literary work make their root in the title. Such spatial adjacency between the text (before and above it) and the title allows the interpretation of the latter, by the classification of Charles Pierce, as an index sign, "correlating with its semiotic object via some actual or physical or imaginary causal link” (Merrell, 2005, 31). The usage of the title also represents a writer's ploy according to the fact this text unit condenses the entire text, revealing its significant prospective-pragmatic potential. In addition, the reflexive activity of the recipient contributes the beneficiation of the title with additional denotative-connotative content, subsequently evolving from nominative to figurative one. A striking example of the kind can be exposed by a simple-structured (noun phrase) verbal-thematic title of a story "The Snows of Amalienborg" by Valentyna Vzdulska (2017), manifesting the following narration about Copenhagen palace complex as winter residence of the Danish royal family. Thorough perusal gradually unmasks the metaphorical and symbolic meaning of the title, while the text covers the story of Pavlo Vivtiuk, an elderly churchwarden, who addresses the Danish Queen Margrethe II, pleading for donation of some funds to the orphanage. In this case, Amalienborg, a proper name that is, gets a strong association with the world's beau monde therefore the author integrates it to the semantic group as follows: Мій дід написав багато таких листів нашим депутатам, телезіркам і дружинам президентів. Але вони не відгукнулися. Тоді він почав писати за кордон 
різним знаменитостям $i$ просити в них допомоги для украӥнських сиріт. Якось він написав навіть Маргарет Тетчер, коли та ще була жива [My grandfather has written plenty of letters of the kind to our deputies, TV-stars, and wives of presidents. Although they have not answered in return. Then he started writing abroad addressing various celebrities seeking help to Ukrainian orphans. Somehow, he wrote even to Margaret Thatcher, when she was still alive]. Given title contains the keyword snows, which duplicates within the text canvas, overgrows with epithets, metaphors, and comparisons: Стоїть на притрушеній снігом площі в Амалієнборзі й визирає Маргрете у згаслих вікнах палаиу [There stands Margrethe on the snow-covered square of Amalienborg or peers out of the extinguished windows of the palace]; Щось там змінилося - застигло, знерухоміло, скуте мінус тридиятьма иілковитої безнадіi [Something changed there, having been frozen, motionless, bound by 30 degrees Celsius of total despair]; У тебе всередині щось перевертається й рипає, як кучугура свіжонаметеного снігу [Yои have something deер in your soul, rolling over and squeaking like a clump of freshly fallen snow]. Likewise, these structures become constituents of the expanded antithesis cold - warm: Одного січневого вечора, вже після свят, ти повертаєшся з танців повз “Корицчю”. [...] Наспівуючи, ти кидаєш погляд у тепле золотисте нутро кав'ярні [Once in a January evening, when all the holidays are through, you come back from dance party along the "Cinnamon". [...] Cantillating, you glance into the warm golden inside of the café]. At the end of the story, this antithesis gets vivid explication, when the writer represents the whole picture from a diametrically opposite point of view, according to the principle of "pointe shoes" as follows: Tu сподіваєшся, що ие буде весна або літо. Сніги Амалієнборгу вже розтануть. Небо з сірого стане блакитним, трава - зазеленіє, на клумбах ивістимуть тюльпани або троянди. А коли ти повернешся, то, може, навіть напишеш декому. I, може, навіть запросиш його в кіно. А потім - у “Корицю”. Тільки не на гарячий шоколад, а на холодний-холодний молочний коктейль, бо ж буде вже тепло [Yоu do hope it is to be spring or summer. The snows of Amalienborg will have already melt. The sky full of grey turns into blue, the grass becomes emeraldgreen; there are tulips and roses flourishing in the flowerbeds. Later, when you are back again, probably you will wright to someone. Maybe you even invite to the movies. Then - to the "Cinnamon". It is not actually about the hot chocolate, but the so cold milk shake, for it will be warm then]. The ending of this kind meaningfully reflects the contents of the title, that is the author's desire to melt down the cold apathy of people. Particularly not only of these who got rid of the ability to empathize due to huge material wealth, but also of those who make the meaningless communication via Internet the higher priority over the useful deed. Thus, the title ascertains the theme of the text in a concise form, enlightening the core plotline of the work and elucidating the semantic and conceptual information, revealed on the background of the whole novel.

Apart of the latter, subheadings, epigraphs, and dedications as other, optional, constituents of the title complex reveal their vivid segmentation. The subheading typically adjusts the perception of the text within all the primarily ascertained genre parameters, corrected by the author: Потерчата. Дитяча сповідь для дорослих, які так нічому й не навчилися [Poterchata. Children's confession for adults, who learned nothing in life] (Rutkivskyi, 2013); Нянька-Ненька. Зі щоденника заробітчанки [Nanny-Muтmу. An ехсегpt from the woman-employee's diary] (Drachkovska, 2009); Грози над туровием: Родинні хроніки [Thunderstorms over Turovets. Family chronicles] (Danylenko, 2014); Депеш Мод. Ще одна розмова [Depeche Mode. One more talk] (Zhadan, 2015). In fact, this part of the text endures the further subdivision into nominative and nominative-stylistic types, where the unification of the second one and the title itself results in double title of the novel, rational and emotional at the same time.

Another significant unit of the text, an epigraph, discloses its profound structure level, simultaneously explicating the author's idea and launching the storyline. An outstanding Ukrainian insurgent song “Буде нам з тобою що згадати... [We'll have much to remember then...]" makes a vivid example of such a component; specific lines of the song constitute an epigraph to some parts of the novel "Marusia” by Vasyl Shkliar (2014), eventually manifesting a close connection with the beginning of the narration. It is worth mentioning that epigraphs have a potential to establish straightforward relationships with a reader and provide an appropriate perception of the text, they attach the addressee to the intertextual dialogue. Up-to-date fiction represents the usage of various in volume epigraphs. In fact, excerpts from poetic and prose texts of the World and Ukrainian literature as well as the Bible occupy a dominant position. Concerning the problem of an epigraph perception, we should expect the reader not to neglect or pay lesser attention to the mentioned above emphasised text unit. Those psychologists (Valentyn Asmus, Lev Vyhotskyi, Lidiia Zhabytska, Borys Korman, Olha Nikiforova, Pavlo Yakobson), who deal with readers' activity issue, highlight the fact that ignoring epigraphs consequently results in the incomplete perception of the given text.

Composing a literary text, the writer also bears in mind creative aptitude of the reader to decipher inscriptions. The importance of the latter for the reader was tested by the scale method on the base of the M. Dziuba's (2003) novel "Covered by the sky" and its inscription. All the respondents were asked to create the subjective space of the citation perception with a help of the scale from 1 to 5 as follows: The novel "Covered by the sky" by M. Dziuba has an inscription "Моїм дорогим краянам присвячую. Будьмо! [Dedicated to my dearest compatriots. Let us live!]”. Reveal the position, by which it ultimately helps you to make an adequate interpretation of the content of the text. Evaluate your own answer on the 1-5 scale. Results are represented in the Tab. 1:

Tab. 1: Functions of Inscriptions

\begin{tabular}{|c|c|c|c|c|c|c|}
\hline № & Function & 1 & 2 & 3 & 4 & 5 \\
\hline 1 & $\begin{array}{l}\text { illuminates the culturological } \\
\text { component of the content }\end{array}$ & & & & & \\
\hline 2 & $\begin{array}{c}\text { makes the reason for author's } \\
\text { sympathies }\end{array}$ & & & & & \\
\hline 3 & $\begin{array}{l}\text { ascertains the depth of author's } \\
\text { emotions }\end{array}$ & & & & & \\
\hline 4 & $\begin{array}{c}\text { determines the role of the author } \\
\text { as medium between the text and } \\
\text { the reader }\end{array}$ & & & & & \\
\hline 5 & $\begin{array}{c}\text { forms an indication for } \\
\text { understanding of author's } \\
\text { intention }\end{array}$ & & & & & \\
\hline 6 & $\begin{array}{l}\text { provides the author with } \\
\text { personal connection to the } \\
\text { reader, opens the possibility to } \\
\text { address the reader directly }\end{array}$ & & & & & \\
\hline 7 & uncovers the title of the novel & & & & & \\
\hline
\end{tabular}

Source: own questionnaire designed specifically for the research.

The results of the experiment manifest that inscription 1) is closely attached to the text by diverse emotional relations (the position was given the highest mark by $90 \%$ of respondents), 2 ) much more distinctively discloses the whole text to the reader (80\%), 3) assuredly, represents a clue to comprehension (70\%).

In modern literary texts, inscriptions predominantly have an anthroponomical "gift inscriptions" pattern: Крістіаніновi, Соломії та Іниим [То Christianine, Solomiia and Others] (Andrukhovych, 2013); Моєму батькові [Tо mу Father] (But, 2015); Любомирові Шкоруті, котрий викупив мене з неволі [To Liubomyr Shkoruta, who redeemed me from the captivity] (Shkliar, 2013). On the one hand, they generate an intimate "aura" around the text, functioning as a text amulet and exposing author's personal memory, on the other hand, they mark specific transition node in the poetic-autobiographical hypertext of the writer. According to the representation mode of the addressee, personal individual inscriptions obtain leading status. 
Inscriptions-dedications unveil author's intention: Моємy Кревному Роду, шо тягнеться живим ланцююгом із гір ілісів i тече рікою Любові через світи й віки [То ту bloodline, stretching like living chain from mountains and forests, flowing like river of Love through the worlds and centuries] (Dochynets, 2013); Присвячується мойй бабиі Олі та дідусеві ІвануМихайлу Гурницьким. Їхне життя було непростим, доля складною, а кохання трагічним, проте вони завжди залишалися для мене зразком інтелігентності, вишуканості та культури, притаманних довоєнному Львову [Dedicated to my grannies Olia and Ivan-Mykhailo Hurnytski. Their life was not easy, their fate was intricate, and Love was tragic; nevertheless, they always have been an example of culture, elegance and standard, inherent in pre-war Lviv] (Hurnytska, 2017). Inscriptions-gratitudes have the same capacity: Ця книжка з'явилась завдяки Андрієві і Мар'яні, які поруч у всі миті, моӥм батькам, які назавжди зарядили мене підтримкою, Ренаті Середнииькій, яка прихистила і зігріла y своєму затишному домі, Жанні Комар, яка підказала стежку до основного джерела, Дані Винницькій, музика якої напуває силами $i$ натхненням, Богдані Матіяш, яка подарувала хрестик, а також всім іншим людям та обставинам, мені подарованим [This book appeared thanks to Andrii and Mariana, who are near in all the moments of my life, thanks to my parents, empowering me with a support; thanks to Renata Serednytska, who gave me shelter and warmth in her cozy house; thanks to Zhanna Komar, who prompted me with a path to the main source; thanks to Dania Vynnytska, the music of whom gives life power and inspiration; thanks to Bohdana Matiiash, who gifted me a cross; also thanks to other people and circumstances, been given to me] (Andrukhovych, 2015). Primarily, all these dedications undergo the subdivision into individual and collective due to the way of addressee performance.

Despite of dissimilar, narrative and discourse, approaches, regulating the interpretation of the beginning and the end of the text, many researches (Iryna Arnol'd, Yuliia Bohatova, Nataliia Bulaieva, Bernhard Korte, Constanze Krings, Kateryna Moskalova, Iryna Stoliarova, Hans-Wilhelm Schwarsze, etc.) came to the point these two positions have a particular importance to the reader. That is, events are perceived based on information, already acquired at the beginning, whilst the end of the text frames their holistic decoding. Usually, the very beginning of the narration has a strong association with the beginning of text events (Schwarsze, 1982), whereas its end is stated by the last passage (Bonheim, 1982, 117), particularly the fragment to disclose the winding up, to manifest the new knowledge, to change velocity and modus of the narration, etc. (Krings, 2003).

No less important are author's preface or prologue - an information of the introductory pattern of the text, considered as rather independent fragments due to the content. However, they are deprived of their significance without the main text, while inside the text itself some information loses its intensity. In fact, prefaces get the reader acquainted with prototypes of characters, auxiliary materials, been used in the main text composition. It is noteworthy that the text constituents hold author's stance towards the depicted future developments. In the preface of her novel "Closed circuit" the author Svitlana Talan (2017), particularly, quite unequivocally settles the angle of the readers' approximate perception via an older soothsayer's aphorisms as follows: Кожен кує свою долю [Everyone is a blacksmith of their own fate], Не будьте поборені злом, але перемагайте зло добротою [Do not be conquered by evil, but overcome evil with kindness], Зло знищує душі [Evil destroys souls], Треба любити ближнього свого, як самого себе [You should love your neighbour as yourself]; Що віддала - те й отримай, бо такий закон життя [You get what you give, that is law of life]. Mostly, prologues are asynchronous by temporal and spatial parameters with the main text, marking likewise prefaces a conceptual information and raising philosophic, moral and ethical issues that comprise the basis of the plotline of the text. Author's afterword or epilogue in their turn appear as specific text patterns to be inferred to; they function mainly to satisfy the interest of those readers who endured narration events particularly emotionally and show great curiosity about the future fate of the characters.

Among the quite common phenomena of the comprehensive fiction, one should also mention the onyms', keywords' and intertextual inclusions' emphasis in diverse macrocontext strong positions, in particular the anthroponym Black Raven, used in the novel "The Remnant" by Vasyl Shkliar (2010), stands for reinterpretation of attributive-substantive collocation black raven, symbolizing wisdom by the Bible version. In such a case, this archetypal onym enlists the reader to some kind of fascinating game, the complexity level of which depends on presuppositional readiness for text perception, and meanwhile attaches them to cultural-semiotic worldview tandem with the author. It is woven into the regulatory microstructure of keywords like vanity over vanities, all is in vain, everything passes, everything is just spinning around and comes full circle, everything goes back to the way it was and there is no new thing under the sun on the base of semantic equivalence, provoking deep thoughts about an insignificance of human life. More than that, the keywords pragmatics reveals subordination to their contact or remote layout: the regulatory microstructure of the keywords' contact location (within the consecutive passages' boundaries) usually exposes author's emotional-evaluative response while the pattern of a remote (dispersed throughout the text) one directs reader's imagination and mind towards the process of reducing the general idea of the text. The latter formed the subject of thorough analysis of respondents as follows: At the very beginning of the novel "The Last Notch" by Tetiana Pyshniuk (2016) readers can come across the collocation red apple, duplicated then for several times within the excerpt. What information, in your opinion, does this repetition highlights?

a) only charismatic personalities have to create a history;

b) we got used to colourless life, so that bright colours sometimes frighten us;

c) the fate of the prominent people is unlikely to be easy;

d) it is hard to identify the semantic load of the given unit on the background of such a small text fragment;

e) your own variant

To sum up, $10 \%$ of respondents chose a, $10 \%$ of them chose b, while $80 \%$ - chose c, and $0 \%$ of respondents to choose d and e.

Nowadays the microcontext techniques of positional emphasis have multifaceted nature and are intensely implied in the modern fiction. They arrange the text constituent updating in the beginning, in the end as well as in certain or unusual positions of the sentence. The spectrum of widely spread regulatory techniques today likewise accommodates identical structure of initial parts of adjoined sentences. Various syntactic commencements, particularly subject, predicate or circumstantial, determine adequate settings for the further reading of the text. Subject commencements, in fact, put forward items of description, while predicate ones make the depicted dynamic and variable and circumstantial patterns emphasise on the special time-space line as follows: I махрова м'якість халата в жовті квіточки була незвично-лагідною, $і$ дотик білизни, постеленої на канапі, був інший, ніжніший, не такий, як вдома. Велюрова м'якість штучного леопарда під рукою, і світло вітражного нічника - сонце крізь льодяникусе оберталося радістю та спокоєм. Кімната зникла в темряві, щзойно натиснула на вимикач... [So then terry soft of a wrapper in yellow flowers seemed unusually gentle and the touch of linen, spread on the couch, was different, gentler, not like home. All of it - velor softness of an artificial leopard coverlet under the arm, and the light of stained-glass night-lamp like sunlight through the sugar-candy-illuminated with joy and peace. The room disappeared in the darkness the very moment the switch was turned off] (Vdovychenko, 2012); Стрекочуть швацькі машинки, щүільно припасовані в кілька рядів уздовж всього цеху в десятки робочих місиь. Строчать деталі пальто і перегукуються між собою дівчата-ивачки [Sewing machines are tightly fitted in several lines along the entire shop 
for dozens of workplaces, chirping. Girls-seamstresses are calling one another, stitching coats' parts] (Lesia Stepovychka, 2012); Восени сорокового року старшого Соломійчиного брата Тараса забрали до Червоної армії. За два тижні до того разом ще $з$ кількома загорєнськими хлопиями його викликали в район - волость по-колишньому, по-иарськи, по польськи - тміна, а може, й повіт ции повят. Та типерка, як совєти прийшли, все було по-новому, по-інакшому, іноді й не розбереш, щзо до чого [In the autumn of 1940 Taras, the older brother of Solomiia, was taken to the Red Army. Two weeks before the occurrence he and some guys from Zahoriany had been summoned to the district centre - the parish as it was once, in the times of tsar, gmina in Polish or formerly county. Nevertheless, right now, as Soviets came, everything seemed new, different, sometimes you hardly understand what is going on] (Lys, 2016).

Marking an important component of the content tend to be sufficiently essential at the beginning of the sentence. Therefore, it is about the consummation of segmented structure with Nominative Case of Imagination as peculiar satellite of the next sentence, in fact, it is created properly for this purpose. The Nominative Case of Imagination actually regulates exclusive psychological tension, the mood of expectation, focusing on the theme, which duplicates in the neighbouring context, frequently with a help of personal or other kinds of pronouns. The repetition of the theme, some specific intonation, and positive / negative mode constitute the profound expression of the utterance as follows: Ранкова пора у місті. Нестямно горять білі свічки каштанів, зоріють світлячки акацій, мов прощальний акорд травня, потужний $i$ n'янкий акорд. Життя триває, видозмінюючи реальність [An early morning in the city. Ecstatic lights of chestnut white candles, starlight of acacias, like farewell chord of May, powerful and heady chord. Life is going on, modifying the reality] (Dara Kornii, 2016); Передова стаття! Я написав передову статтю до газети [The front-rank article! I have written a front-rank article for the newspaper] (Andrukhovych, 2012). Concerning the regulatory potential of segmented structures with Nominative Case of Imagination, it is worth mentioning that they objectify philosophical reflections of the author, provoke the situation of core historical events' remembrances, and deepen the inner traits of characters.

Such positional kinds of repetitions as anaphora, epiphora, anadiplosis, and epanode also illustrate the mentioned above law of Hermann Ebbinghaus. These powerful syntactic-stylistic speech inversions contribute to more intense conviction of text fragments, indicating balanced thoughts of the author. Generally, the content emphasis by positional repetitions may even become the predominant authorial technique, vigorously exemplified in the novella "I live with a monster" by Halyna Tarasiuk (1995), expressed right through by initial tautological components (for example, I так, обнявиись, завмираємо. Двоє монстрів. Двоє нещасних самотніх калік. Двоє самогубиів, пришитих одне до одного долею [And so, embracing, we swoon. Two monsters. Two unhappy lonely cripples. Two suicides, sewn to each other by the fate]), final repetitions (Він любить порядок. За ие його поважаю. Коли головував - у селі був порядок. Тепер - нема. Хто щчо хоче, те й робить. Ніхто нікого не бойться. $A$ треба, цоб народ боявся. Коли не Бога, то власті. Тоді буде толк. I порядок [He loves order. I respect him for that. There was an order in the village when he was a head of the collective farm, right now - an opposite. Everyone does what he wants. Nobody feels fear towards anyone. The folk have to fear. If it is not God, then it is authorities. Only then, it would be a sense and an order]), the junction of the finite unit of the previous sentence and the initial unit of the following syntactic structure ( $Я$ знаю: ие він лається. Він лається навіть уві сні; Але - мовчу. Мовчу $i$ терплю [I just know: he swears. He swears even sleeping, but - I keep silence. I keep silence and tolerate]), moreover, by the chiasm, built on the base of such the junction (На старість кожен має те, щуо заслужив. Ми теж заслужили те, що маєм [In old age everyone gets what he deserves. We really deserved what we have now]).
As a rule, the reader's attention may be drawn by the object, which, unlike others, occupies a separate position. In such a case, we study the paragraph separation of the sentence or even the word as regulatory technique of positional emphasis as follows: Бо дім - то не лише гніздо, а точка, з якої ти бачиш Всесвіт $і$ звідки Всесвіт сприймає тебе [Весаиsе home is not just family nest, but the point you observe the Universe from, and the Universe perceives you as well] (Ponomarenko, 2016); Час - дивна річ [Time is a strange thing] (Iren Rozdobudko, 2011). It is well known that the dominant criterion of the paragraphs graphic division in the literary text - a thematic one has gone levelled. Under these circumstances, the text content constituents' combining serves as a specific hint to the appropriate processing of intellectual and emotional information by the recipient, focusing on readers' empathy as well as on their "catharsis".

Specific text position is an inherent trait of the text elements limited via parcelling. Created by the sentence breakdown, emphatically strengthened parcelates actualize information, which is crucial according to the author's intention, and help to avoid ambiguity. In the modern fiction, there are main and secondary parts of sentence, parcelling as follows: Biк, знаєme. Порода. Досвід [It is an age, you know. The breed. The experience] (Matios, 2011); Бачити я не міг. Чути теж [I could not see anything. Hear as well] (Chekh, 2007); Ідучu, раптом зауважив, що досі не розплющив очей. Проте бачив усе в кімнаті досконало [While walking, he suddenly observed he had not still opened his eyes. Nevertheless, he could perfectly see every object in the room] (Irvanets, 2010); Вона cmиха посміхнулася. Ледь-ледь [She softly smiled. Just barely] (Lys, 2015).

Whist reading the text, readers get the landmark in content deciphering via the unusual position of text components. This fact makes a touchstone of a stylistic inversion, the technique that opens the further possibility to move the logical emphasis. In consequence, the inverted element acquires pragmatic connotation: Про мою ворожбу з псами скоро дочулися zocnodapi [Soon the hosts have heard about my divination with dogs] (Dochynets, 2012); Від палісадника під Жориним будинком долинають пахощі - там мліють на сониі мальви, хрін з кропом $i$ оранжево-багряне квіткове буйство, в різновидах якого Пашок розуміється слабо [A smell of a perfume reach over there from the front garden of Zhora's house - there are mallows, horseradish with dill, and orange-purple luxuriance grind in the sun, Pashok has a very little to do with its varieties] (Volvach, 2004). Such a distinguishing word order, by S. Göpferich, correlates with a simultaneous transfer of the theme to the very end and the rheme - to the very beginning of the sentence structure. The researcher is profoundly convinced that the speaker satisfies the emphase of the message this way and concurrently highlights an intense informative value of the rheme (Göpferich, 2008, 85). This statement was sufficiently confirmed throughout the experiment, targeting in comparison of the original sentence with inversion and transformed sentence without it as follows: The author applies the indirect words order in the sentences of the given text. Please, compare the original unit with inversion Аня чомусь не дуже впевнено про uе думала [Anne was thinking about it somehow not quite confidently] and the transformed unit without inversion Аня думала про че чомусь не дуже впевнено [Somehow, Anne was thinking about it not quite confidently]. Do they differ in semantic nuances, in your opinion?

a) the content of both units is identical;

b) Anne's uncertainty is expressed more vividly in the first unit;

c) Anne's uncertainty is expressed more vividly in the second unit;

d) other observations

Almost 95\% of respondents chose variant b. Thus, in modern fiction the communicative structure of diverse syntactic units, built on the base of inversion, irrefutably ascertains the fact the first-rank content is usually located in the postposition of the 
sentence, though sometimes its beginning "extrapolates not necessarily new but especially relevant for the addressee information" (Blumenthal, 1987, 45). As a rule, the final constituent of the sentence produce an objective information, while the initial component is subjective, being connotative and dramatic as well.

\section{Conclusions}

The expressive-stylistic tools forms the fundamental of the regulatory macro- and microcontext techniques of positional emphasis in modern Ukrainian. These techniques open the further perspective to systematise particular - framework regulatory microstructures in literary texts. There is a tight hierarchical relation between text units within such microstructures; the consecutive removal of the mentioned above text units may cause the loss of the structural integrity of the text and of its content as well.

Up-to-date positional emphasis represents one of the powerful ways of regulating the reader's perception of the text information. Thus, the given research does not embrace all the possible aspects, but contributes to the problem of constructive dialogue formation between the author and the recipient, making the vector for its future in-depth investigation.

\section{Acknowledgements}

The given article has no special external financial support and is funded only by means of personal incomes of the authors.

\section{Literature:}

1. Ebbinghaus, H.: Uber der gedächtnis. Untersuchungen zur experimentellen Psychologie [About the memory. Research on experimental Psychology]. Darmstadt: WBG Academic, 2011. 128 p. ISBN 978-3-53424-012-8.

2. Roeskelein, J.: Elsevier's dictionary of psychological theories. Burlington: Elsevier, 2006. 692 p. ISBN 978-0-4445-1750-0.

3. Arnol'd, I. V.: Znacheniye sil'noy pozitsii dlya interpretatsii khudozhestvennogo teksta [The significance of the strong position for the interpretation of the literary text]. In: Foreign Languages in School. 1978. No. 4, pp. 23-31. ISSN 0130-6073. 4. Merrell, F.: Charles Sanders Peirce's concept of the sign. In: The Routledge Companion to Semiotics and Linguistics. London and New York: Taylor \& Francis e-Library, 2005, pp. 28-39. ISBN 0-41524-313-0.

5. Vzdulska, V.: Snihy Amaliienborhu [The Snows of Amalienborg]. In: Chat dlia divchat [Chat for girls]. Lviv: Vydavnytstvo Staroho Leva, 2017, pp. 45-56. ISBN 978-617-679-286-4.

6. Rutkivskyi, V.: Poterchata. Dytiacha spovid dlia doroslykh, yaki tak nichomu y ne navchylysia [Poterchata. Children's confession for adults, who learned nothing in life]. Ternopil: Navchalna knyha Bohdan, 2013. 256 p. ISBN 978-966-10-3146-2.

7. Drachkovska, O.: Nianka-Nenka (zi shchodennyka zarobitchanky) [Nanny-Mummy. An excerpt from the womanemployee’s diary]. Lviv: Kalvariia, 2009. 192 p. ISBN 978-966663-265-7.

8. Danylenko, V.: Hrozy nad Turovtsem: Rodynni khroniky [Thunderstorms over Turovets. Family chronicles]. Lviv: Literaturna ahentsiia «Piramida», 2014. 370 p. ISBN 978-966-441-347-0.

9. Zhadan, S.: Depesh Mod. Shche odna rozmova [Depeche Mode. One more talk]. Kharkiv: Klub simeinoho dozvillia, 2015. 240 p. ISBN 978-966-14-9096-2.

10. Shkliar, V.: Marusia [Marusia]. Kharkiv: Klub simeinoho dozvillia, 2014. 320 p. ISBN 978-966-14-7838-0.

11. Dziuba, M.: Ukryti nebom [Covered by the sky]. IvanoFrankivsk: Tipovit, 2003. 240 p. ISBN 966-8098-06-5.

12. Andrukhovych, Y.: Dvanadtsiat obruchiv [Twelve hoops]. Kharkiv: Klub simeinoho dozvillia, 2013. 288 p. ISBN 978-96614-4812-3.

13. But, S.: Lysty $z$ toho svitu [Letters from the netherworld]. Kharkiv: Klub simeinoho dozvillia, 2015. 300 p. ISBN 978-96614-8331-5.

14. Shkliar, V.: Elemental [Elemental]. Kharkiv: Klub simeinoho dozvillia, 2013. 224 p. ISBN 978-966-14-4815-4.
15. Dochynets, M.: Horianyn. Vody Hospodnikh rusel [Highlander. Waters of Lord's channels]. Mukachevo: Karpatska vezha, 2013. 311 p. ISBN 978-966-8269-36-3.

16. Hurnytska, N.: Melodiia kavy $v$ tonalnosti spodivannia [The coffee tune in the mode of hope]. Kharkiv: Klub simeinoho dozvillia, 2017. 256 p. ISBN 978-617-12-2260-1.

17. Andrukhovych, S.: Feliks Avstriia [Felix Austria]. Lviv: Vydavnytstvo Staroho Leva, 2015. 280 p. ISBN 978-617-679-082-2. 18. Schwarsze, H.-W.: Ereignisse, Zeit und Raum, Sprechsituationen in narrative Texten [Events, time and space, speech situations in narrative texts]. In: Ludwig H.-W. Arbeitsbuch Romananalyse [Workbook of novel analysis]. Tübingen: Narr, 1982. 260 p., pp. 145-188. ISBN 978-3-87808-932-2.

19. Bonheim, H.: The Narrative Modes. Techniques of the Short Story. Cambridge: Totowa, NJ by D. S. Brewer, 1982. 197 p. ISBN 0-85991-086-5.

20. Krings, C.: Zur Typologie des Erzählschlusses in der englischsprachigen Kurzgeschichte [The typology of the narrative in the English-language short story]. Frankfurt-Berlin: Peter Lang, 2003. 206 p. ISBN 978-3-63150-356-0.

21. Talan, S.: Zamknene kolo [Closed circuit]. Kharkiv: Klub simeinoho dozvillia, 2017. 320 p. ISBN 978-617-12-2273-1. 22. Shkliar, V.: Zalyshenets [The Remnant]. Kharkiv: Klub simeinoho dozvillia, 2010. 384 p. ISBN 978-966-14-0662-8.

23. Pyshniuk, T.: Ostannia zarubka: uryvky z romanu [The Last Notch: excerpts from the novel]. Slovo prosvity [The Word of Education]. 2016. No. 34 (August 25-31), pp. 8-9.

24. Vdovychenko, H.: Kupalnytsia [The Bather]. Kharkiv: Klub simeinoho dozvillia, 2012. 240 p. ISBN 978-966-14-4230-5.

25. Stepovychka, Lesia: Myr, druzhba, zhvachka, abo kontrakt z tovaryshem Lunacharskym [Peace, friendship, chewing gum or the agreement with comrade Lunacharskyi]. Nimtsi v horodi [Germans in the city]. Vol. 1. Dnipropetrovsk, 2012. 406 p., pp. 11-186. ISBN 978-966-383-388-0.

26. Lys, V.: Solo dlia Solomii [Solo for Solomiia]. Kharkiv: Klub simeinoho dozvillia, 2016. 363 p. ISBN 978-966-14-5688-3.

27. Kornii, Dara: Honykhmarnyk [The Cloud-Driver]. Kharkiv: Klub simeinoho dozvillia, 2016. 332 p. ISBN 978-966-14-1009-0.

28. Andrukhovych, Y.: Taiemnytsia. Zamist romanu [A Mystery. Instead of the novel]. Kharkiv: Folio, 2012. 480 p. ISBN 978966-03-4392-4.

29. Tarasiuk, H.: Ya zhyvu z monstrom [I live with a monster]. Liubov i hrikh Marii Mahdalyny [The love and the sin of Mariia Mahdalyna]. Chernivtsi, 1995. 384 p.

30. Ponomarenko, L.: Nekhvoroshch [Artemisia]. Poltava: Dyvosvit, 2016. 192 p. ISBN 978-617-633-163-6.

31. Rozdobudko, Iren: Amulet Paskalia [Pascal's amulet]. Kharkiv: Folio, 2011. 190 p. ISBN 978-966-03-2766-5.

32. Matios, M.: Chotyry pory zhyttia [Four seasons of life]. Lviv: Literaturna ahentsiia "Piramida”, 2011. 264 p. ISBN 978-966-441-213-8. 33. Chekh, A.: Tsoho vy ne znaidete $v$ Yandeksi [You are not to find this in Yandex]. Kharkiv: Folio, 2007. 224 p. ISBN 978966-03-3898-2.

34. Irvanets, O.: Khvoroba Libenkrafta [The illness of Libenkraft]. Kharkiv: Folio, 2010. 192 p. ISBN 978-966-03-5310-7.

35. Lys, V.: Kraina hirkoi nizhnosti [The land of bitter tenderness]. Kharkiv: Klub simeinoho dozvillia, 2015. 368 p. ISBN 978-966-14-8772-6.

36. Dochynets, M.: Krynychar. Diiariiush naibahatshoho cholovika Mukachivskoi dominii [Sourcerer. The diary of the richest man in the Mukachevo dominion]. Mukachevo: Karpatska vezha, 2012. 332 p. ISBN 978-966-8269-30-1.

37. Volvach, P.: Kliaksa [A Blot]. Ternopil: Dzhura, 2004. 284 p. ISBN 966-8017-89-7.

38. Göpferich, S.: Textproduktion im Zeitalter der Globalisierung: Entwicklung einer Didaktik des Wissenstransfer [Text production in the age of globalization: Development of a didactics of knowledge transfer]. Tübingen: Stauffenberg-Verlag, 2008. 499 p. ISBN 978-3-86057-254-2.

39. Blumenthal, P.: Sprachvergleich Deutsch-Französisch [Language comparison German-French]. Tübingen: Niemeyer, 1987. 136 p. ISBN 978-3-48454-029-3.

Primary Paper Section: A

Secondary Paper Section: AI 